Article

\title{
The Relationship between Educational Pathways and Occupational Outcomes at the Intersection of Gender and Social Origin
}

\author{
Barbara Zimmermann * and Simon Seiler \\ Institute of Sociology, University of Bern, 3012 Bern, Switzerland; E-Mails: barbara.zimmermann@soz.unibe.ch (B.Z.), \\ simon.seiler@soz.unibe.ch (S.S.) \\ * Corresponding author
}

Submitted: 27 February 2019 | Accepted: 31 July 2019 | Published: 5 September 2019

\begin{abstract}
In this article, we are interested in the differences in the educational pathways and subsequent labour market outcomes by social origin and gender. We apply sequence analyses to model the educational trajectories and conduct regression analyses to determine how the individual's own social status and the salary at labour market entry differs. First, our results show that educational pathways vary by parental status and gender when controlling for reading and mathematics/science skills. Men and pupils with a lower socioeconomic background are overrepresented in vocational education, whereas women and pupils with a more privileged socioeconomic background more often pursue general and academic tracks. Second, these different trajectories lead to unequal occupational status and income. Besides these indirect effects, significant direct effects of parental status and gender on the individual's own occupational status and salary can be found. Together, these findings provide a broad overview of the emergence of inequalities by gender and social origin over the early life course, ranging from differences in skills learned in school to labour market outcomes.
\end{abstract}

\section{Keywords}

education; gender; inequality; labour market; social origin; wage gap

\section{Issue}

This article is part of the issue "Types of Education, Achievement and Labour Market Integration over the Life Course", edited by Irene Kriesi (Swiss Federal Institute for Vocational Education and Training, Switzerland) and Juerg Schweri (Swiss Federal Institute for Vocational Education and Training, Switzerland).

(C) 2019 by the authors; licensee Cogitatio (Lisbon, Portugal). This article is licensed under a Creative Commons Attribution 4.0 International License (CC BY).

\section{Introduction}

Unequal opportunities for attaining higher education or a decent salary can intersect and combine to cumulative (dis)advantages. When Ralf Dahrendorf wrote his "plea for an active education policy" under the title "Education is a Civil Right" (Dahrendorf, 1965) in the 1960s, he mentioned three main groups of children that were being underrepresented in secondary school: rural children, working-class children, catholic children (with some reservations), and girls. While Dahrendorf was aware that these groups may intersect, he did not further investigate this circumstance. Nevertheless, the artificial Figure of the "catholic working-class girl from the countryside" was born (Allmendinger, Ebner, \& Nikolai, 2010; Becker, 2007; see also Peisert, 1967). With social changes, such as, for example, the expansion of education, post-industrialisation, increasing globalisation and (at least in legal terms) gender equality, the symbolic figure of cumulative educational disadvantage has transformed from the "worker's daughter" to the "migrant son" (Geißler, 2005). Indeed, girls caught up with boys in their educational attainments and have even started to outnumber them in terms of higher educational qualifications (C. Buchmann \& DiPrete, 2006; DiPrete \& Buchmann, 2013). However, this should not hide the fact that first, improved education has not translated into equal work opportunities for men and women 
(Blau \& Kahn, 2017; Charles, 2011) and second, persons with a lower socioeconomic family background may not only be disadvantaged in the education system, but also in the labour market (Mood, 2017).

In the current research, we are interested in how social origin and gender interact and shape early life courses from the end of compulsory school to the first years in the labour market. The questions we try to answer in this article are the following:

1. Are there differences in student performance by parental status and gender?

2. Are there differences in educational pathways by parental status and gender, overall and net performance (primary and secondary effects of social origin)?

3. Do these differences lead to unequal outcomes in young adults' early working life, namely occupational status and income?

Our main interest lies in describing the overall relationship between parental status and gender and educational trajectories, as well as subsequent labour market outcomes, rather than in identifying causal mechanisms that might be responsible for the differences. Theoretically, we combine two lines of argumentation: First, we draw on the literature on primary and secondary effects of origin (Boudon, 1974; Bourdieu \& Passeron, 1971; Breen \& Goldthorpe, 1997). Second, we complement this with theories on gender segregation in education and employment (Charles \& Bradley, 2002, 2009). Throughout the article, we adopt an intersectional approach that considers different dimensions of social inequality simultaneously (McCall, 2005). For our analyses, we draw on a unique longitudinal dataset that covers Swiss adolescents from the moment they took the Programme for International Student Assessment (PISA) Test in the year 2000 until 2014, when they were around 30 years old. To take advantage of the panel data, we model the pathways of post-compulsory education using sequence analysis. Compared to previous research, our article has the advantage of offering a broad view on emerging inequalities by gender and social origin, and, thus, contributes to a general understanding of processes translating unequal opportunities into inequalities in outcomes.

\section{Previous Research and Theoretical Background}

Research in educational inequalities is often based on the theories of primary and secondary effects of social origin, initiated by the seminal work of Boudon (1974) and further developed by many others (Breen \& Goldthorpe, 1997; Erikson \& Jonsson, 1996). Briefly, primary effects indicate that children from different social origins differ in their school performance. Children born into higher social classes generally perform better in school because they have more economic and cultural resources at their disposal that lead to more educationspecific support (Becker \& Lauterbach, 2010). In addition to these primary effects, children from a higher social origin reach higher levels of educational achievement, even if their performance is equal to that of their counterparts from a lower social origin. In the literature, these secondary effects of social origin have been explained by differential decisions based on rational cost-benefit calculations. According to the relative risks aversion model (Breen \& Goldthorpe, 1997), the main aim is to obtain as much education as is necessary to avoid downward mobility (compared to the social position of the parents). More cultural approaches indicate that different educational decisions by social class could also be due to subcultural norms concerning the value of education, caused for example by class-specific socialisation or by a desire for conformity (Paulus \& Blossfeld, 2007).

A few studies have taken an intersectional approach to analyse the effects of different ascriptive characteristics on school performance (primary effects). They mainly find that boys with a low socioeconomic family background particularly perform worse at school (Entwisle, Alexander, \& Olson, 2007; Glaesser \& Cooper, 2012). Strand (2014) does not find any interactions between socioeconomic status and gender. Gottburgsen and Gross (2012) additionally find heterogeneous effects, depending on whether reading or mathematics skills are concerned (see also Becker \& Müller, 2011). Intersectional approaches assessing secondary effects are less common. Breen, Luijkx, Müller and Pollak (2009), as well as Becker and Müller (2011), take a historical approach and try to assess how educational expansion and increasing gender equality in education interact. They show that gender and class differences in educational inequality have declined. While Becker and Müller (2011) find that gender differences in class inequalities have changed over time, according to Breen et al. (2009) they have remained rather stable. Explanations for why gender differences vary by social class have been rather vague so far. The main argument is that gender stereotypes, such as beliefs in gender-specific traits or personality differ by social class (see for example Kriesi \& Buchmann, 2014).

Primary and secondary effects of social origin do not only influence the level of education one attains, but there is also a horizontal dimension to it. In other words, within a certain level of education, students from different class backgrounds do not necessarily study the same subjects (Becker, Haunberger, \& Schubert, 2010; Reimer \& Pollak, 2005; van de Werfhorst, 2002). Such horizontal differences are relevant because they may translate to vertical stratification as fields of study differ in terms of subsequent labour market opportunities (Reimer \& Pollak, 2005). Theoretically, several mechanisms can lead to these differences. According to van de Werfhorst (2002), there is a cultural aspect of intergenerational transmission. Children get more information on the fields of study of their parents and are there- 
fore more likely to choose a similar subject. Reimer and Pollak (2005) indicate further aspects that may lead to different choices of field of study by social origin that are drawn from rational choice considerations, namely the perceived difficulty of a subject, the study duration, subsequent job security and opportunities to attain a favourable class position and achieve high incomes (Reimer \& Pollak, 2005, p. 7). For a more detailed discussion of the primary and secondary effect on the choice of the subject of study, see also Becker et al. (2010).

Glauser (2015) discusses how the mechanisms of primary and secondary effects shape gender differences in educational outcomes. Primary gender effects emerge because girls generally show a greater willingness to learn, have a more positive attitude towards school than boys and, as a result, achieve better school grades on average (Glauser, 2015, Chapter 4.3.2). Secondary effects can be identified by the fact that girls are more likely than boys to choose more demanding training paths at the same levels of performance. In the Swiss education system, this happens mainly because they have restricted career prospects within vocational education, which is historically rooted in the highly gender-segregated manufacturing and industrial sector (Imdorf \& Hupka-Brunner, 2015; Imdorf, Sacchi, Wohlgemuth, Cortesi, \& Schoch, 2014). Hence, for boys, vocational education is more attractive because they find a wide range of male-typical occupations that offer good career prospects, including, for example, opportunities for further education (Glauser, 2015).

Ultimately, we assume that gender differences in educational pathways are mainly due to horizontal segregation and that this can lead to vertical stratification. However, we believe that horizontal segregation in vocational education and fields of study is not merely due to differential career prospects for men and women, but that it is rooted in a very persistent "gender-essentialist ideology" (Charles \& Bradley, 2009). This gender ideology adheres to beliefs in differences between men and women, in how they are and how they ought to be (Eagly \& Sczesny, 2008). Accordingly, social roles such as occupations are also gendered. As such, technical or manual occupations, as well as leadership positions, are considered to be more typically masculine, whereas caring or teaching domains are seen as intrinsically feminine. According to the role congruity theory (Eagly \& Diekman, 2006; Eagly \& Karau, 2002), people try to act in a manner that is consistent with their gender, because if they do not, they may face negative consequences. This genderessentialist ideology is very deeply rooted. For example, Schwiter et al. (2014) have shown that boys and girl develop occupational preferences and aspirations that correspond to their own gender at a very early age (see also M. Buchmann \& Kriesi, 2012).

Whether these gender stereotypes differ by social class is less researched (for a detailed account of gender and class stereotyping in an elite labour market see
Rivera \& Tilcsik, 2016). England (2010) argues that as long as upward mobility (or at least avoidance of downward mobility) is possible within ones gender-typical occupations, people will tend to continue to choose a field of study or a job that corresponds to their own gender. Consequently, for lower and middle-class women, it is easier to remain in a gender-segregated female job, while for upper-class women this is less true, as femaletypical jobs are often lower in status (England, 2010). This means that the interplay between gender and social origin shapes young adults' school trajectories and subsequently influences their labour market opportunities.

In sum, although the mechanisms might not be the same, the choice of field of study simultaneously differs according to social origin and gender. So far, analyses mainly of gender sociology and labour economics have focused on horizontal gender segregation, while research into educational sociology has dealt with both aspects, gender segregation and segregation by parental status, but not conjointly. We, therefore, attempt to consider both gender and social stratification in the educational trajectory, including aspects of horizontal and vertical segregation.

Vocational education plays an important role in Switzerland's dual training system. It offers different possibilities to access tertiary level education, such as, for example, colleges of higher education, universities of applied sciences and, in some cases, universities. However, the ideal route to university continues to be via baccalaureate school. For more detailed information on the Swiss educational system, see for example Imdorf, Koomen, Murdoch and Guégnard (2017), Glauser (2015, Chapter 2.1) or Imdorf and Hupka-Brunner (2015).

In line with the theories above and due to the specificity of the Swiss educational system, it can be assumed that the higher the socioeconomic status of the parents, the better the school performance of children and the more likely it is that they will follow an academic educational trajectory. We believe that this is more the case for girls than for boys, because vocational education, including further training in male-dominated occupations, offers more beneficial educational and, subsequently, job opportunities for boys than for girls. Access to femaletypical jobs in the health sector and teaching is provided via general schools at the secondary level. ${ }^{1}$

\section{Data and Methods}

\subsection{Data}

We use the Swiss data from PISA 2000 (Adams \& $\mathrm{Wu}, 2003)$ and the subsequent panel data of TREE (Transitions from Education to Employment; 2016), which is a follow-up panel of students who have participated in the PISA 2000 survey, consisting of 9 waves, collected between 2001 and 2014. We only consider persons who participated in each of the nine waves. This con-

\footnotetext{
${ }^{1}$ For younger cohorts, this is less so the case. In 2002, the healthcare assistant apprenticeship was created and it is now an important route to nursing.
} 
siderably reduces our sample but is necessary to conduct the sequence analysis.

To analyse students' skills in reading, mathematics and science, we used the "Warm estimates" from the PISA 2000 database. These scores consist of the weighted averages of correct answers to all questions of a specific category. The weighting procedure follows Warm's (1989) method of a weighed likelihood estimate (WLE). The main focus of the PISA 2000 tests was reading skills. All students answered the reading assignments, but half of them answered only either the mathematics or the science tasks. To reach a larger number of cases we combined the two scores of mathematics and science. We used the scores from the tests that students have taken, whether mathematics or science. If both tests were taken, we calculated their mean score. Another variable used from the PISA database is the socioeconomic status of the parents. We use the international socioeconomic index (ISEI), either from the father or the mother, depending on which one is higher (dominance approach). This score is based on the students' information on their parents' occupation (Adams \& Wu, 2003). We are aware that the socioeconomic status only measures one aspect of social origin and that there are also other, especially cultural, aspects to it, often measured by parental education. These different resources may have distinct effects in intergenerational transmission. Specifically, Marks (2011) argues that parental education is more important for children's school success than parental class. Education is important, as highly educated parents are better able to help their children with homework and exam preparations. On the other hand, high-status families have more economic resources, which are also beneficial for children's school success. Further, mothers and fathers may not have the same influence on sons and daughters (Korupp, Ganzeboom, \& Van Der Lippe, 2002). While the role of the mother has been ignored for a long time, more recent studies also take her into account (Beller, 2009; Korupp et al., 2002). Some authors combine the different cultural and economic aspects of the social origin of the mother and the father in one multidimensional variable (Blossfeld, 2019; Marks, 2011; Meraviglia \& Buis, 2015). This strategy has some advantages, namely approaching social origin in a more comprehensive way and taking the whole family as a unit of analysis.

We apply the dominance method and use the highest parental ISEI as a proxy for social origin. This way we are able to maintain the descriptive strength of our analyses. Using the ISEI allows us to predict our outcomes over the whole distribution of the parental status, which cannot be achieved in an intuitively understandable way with a multidimensional approach. Further, our main outcomes are the person's own socioeconomic status and their salary, which justifies using parental occupational status as an explanatory variable. Using the dominance approach, mothers may not be adequately represented. In our case though, the highest parental ISEI is the father's in $60 \%$ of the cases, whereas the mother's ISEI is higher in $40 \%$ of the cases. We conducted some additional robustness checks, using the highest parental education instead of the ISEI, which leads to largely comparable results to those based on parent's ISEI (see Section 5).

In each of the nine cross-sectional waves, the school and work situation of the participants was recorded in detail. Additionally, TREE provides an episodic dataset for the job episodes 2003-2014 and a beta version of educational episodes 2010-2014. For the time before 2010, we had to rely on cross-sectional information on the individuals' educational status to construct the episodes. In a further step, we merged the datasets of education and the job episodes and constructed a variable called "state" that indicates the education or job state of each episode, which has the following values:

- Vocational education and training (VET) at the secondary level (e.g., apprenticeship);

- Upper secondary specialised school (secondary, spec.) (e.g., schools that prepare for further education, mainly in the health sector);

- General secondary education (secondary, academic) (e.g., baccalaureate school);

- Tertiary vocational education (e.g., technical school, upper vocational school, federal exams, college of higher education);

- University of applied sciences;

- University of teacher education;

- University;

- Advanced studies (Certificate / Diploma / Master of advanced studies);

- Other education or training (e.g., internships, language schools);

- Employed;

- NEET (neither in education nor employed).

Besides the educational clusters based on these states (see next paragraph), our main outcome variables are the individuals' own socioeconomic status and their income in 2014, at around age 30 . To measure the socioeconomic status, we constructed the ISEI from the ISCO-08 provided in the TREE data. We use the last available observation, which is 2013 or 2014 for around $95 \%$ of the individuals. In the regression models, we add a control variable that indicates whether the measurement of the ISEI is current or not. The income variable displays the gross monthly salary in 2014 in Swiss francs, standardised on a fulltime position (maximum 42 hours per week; for more details see Gomensoro et al., 2017, p. 33), and logged when used in regression models. Some of the respondents had several jobs at the time. As there is no clear information in the data on which is the most important job, we chose to consider the job with the highest income. Table 1 displays the (weighted) frequencies, means (or proportions if the variable is binary) and standard deviations of all used variables for men and women separately. Our sample consists of 907 men and 1353 women who have participated in each wave. 
Table 1. Descriptive statistics. Source: PISA (2000) and TREE waves 1-9 (weighted; 2016).

\begin{tabular}{|c|c|c|c|c|c|c|}
\hline & \multicolumn{3}{|c|}{ Men } & \multicolumn{3}{|c|}{ Women } \\
\hline & $\mathbf{N}$ & Mean & St.Dev. & $\mathbf{N}$ & Mean & St.Dev. \\
\hline Warm estimate in reading & 905 & 503.468 & 85.849 & 1351 & 529.380 & 83.424 \\
\hline Warm estimate in mathematics & 506 & 564.419 & 87.709 & 764 & 538.602 & 87.680 \\
\hline Warm estimate in science & 503 & 526.138 & 87.667 & 728 & 515.523 & 85.639 \\
\hline Warm estimate in mathematics/science & 804 & 549.427 & 87.167 & 1186 & 528.824 & 84.437 \\
\hline Highest parental ISEI & 887 & 49.849 & 16.460 & 1337 & 50.030 & 17.134 \\
\hline Vocational & 907 & 0.606 & 0.489 & 1353 & 0.496 & 0.500 \\
\hline Voc. \& Tertiary & 907 & 0.153 & 0.360 & 1353 & 0.056 & 0.229 \\
\hline Specialized Sec. \& Tertiary & 907 & 0.007 & 0.084 & 1353 & 0.124 & 0.330 \\
\hline Academic Mixed & 907 & 0.057 & 0.232 & 1353 & 0.102 & 0.303 \\
\hline Academic & 907 & 0.177 & 0.382 & 1353 & 0.223 & 0.416 \\
\hline Current ISEI & 872 & 55.793 & 20.741 & 1295 & 57.732 & 19.290 \\
\hline Std. monthly gross salary & 761 & 7121.236 & 3619.881 & 1136 & 6575.126 & 3662.414 \\
\hline
\end{tabular}

\subsection{Methods}

Empirically, we apply sequence and regression analyses. From the episodic data, we have constructed sequences with monthly information on the education or employment status of each individual. To make sense of the multitude of sequences, we have formed clusters of sequences using the dynamic hamming procedure (Lesnard, 2010), which is a variant of optimal matching. It is especially suitable when all sequences have the same length. The optimal matching procedure compares each sequence with every other and calculates the distances between them. The least number of transformations necessary to match the two sequences determines the dissimilarity between them (see for example Halpin, 2010; Lesnard, 2006, 2010). This procedure results in a distance matrix that contains distances between all individual sequences. In a second step, this distance matrix is used for cluster analysis. Similar sequences will then be grouped together in clusters of educational trajectories (e.g., Brzinsky-Fay \& Kohler, 2010). We have performed the calculations with the SADI package for Stata (Halpin, 2017).

To test our assumptions, we conducted several regression models. First, we estimated linear regressions to test the primary effects of social origin on reading and mathematics/sciences skills. To take an intersectional approach, we inserted an interaction term of parental ISEI and gender. Second, we applied a multinomial logit model to estimate the probability of pursuing a particular educational trajectory, conditional on gender and parent's ISEI (including a model net of reading, mathematics/science skills). Third, we conducted linear regressions to estimate the association between social origin and gender and the persons own social status and their income at age 30. We estimated an additional model, controlling for the educational trajectory. Finally, we also estimated the effects of the educational trajectory on own status and salary. For all analyses, we take into account TREE's survey design, which includes calculating clustered standard errors and applying survey weights that also correct for panel attrition (see Sacchi, 2011).

\section{Empirical Findings}

The first step of our analyses addresses the primary effects at the intersection of social origin and gender. We do so by analysing differences in both reading skills and mathematical and science skills by parental ISEI and gender. Consistent with the existing literature we find differences in school performance (see Figure 1 and Table 2). Pupils coming from families with a high socioeconomic status tend to perform better than pupils from less affluent families. In addition, we confirm previous findings, showing better reading skills for girls and better mathematical and science skills for boys (contrasts female vs. male: $26.3, p<0.001$ and $-21.8, p=0.002$ respectively).

Next, the sequence and cluster analyses determine the educational trajectories of our sample. We found a solution of five clusters to be appropriate. Figure 2 shows the distribution of men and women in those clusters. The first cluster mainly contains the trajectories of vocational education at the secondary level followed by employment or to a lesser extent, by subsequent vocational education at the tertiary level (e.g., college of higher education). This is the most common educational pathway of this cohort, the difference compared to the other clusters is especially pronounced for men. The second cluster differs in the respect that the vocational education at the secondary level is followed by tertiary education, mainly at a university of applied sciences. Men also follow this educational path more frequently than women do. The third cluster is the smallest one in terms of the number of students who chose this educational pathway and it is even more gendered than the previous two: Specialised secondary education that is followed mainly by tertiary vocational education or university of applied sciences and, to a lesser extent, university of teacher education is almost uniquely feminine. The reason for that is that these specialised secondary schools mainly 


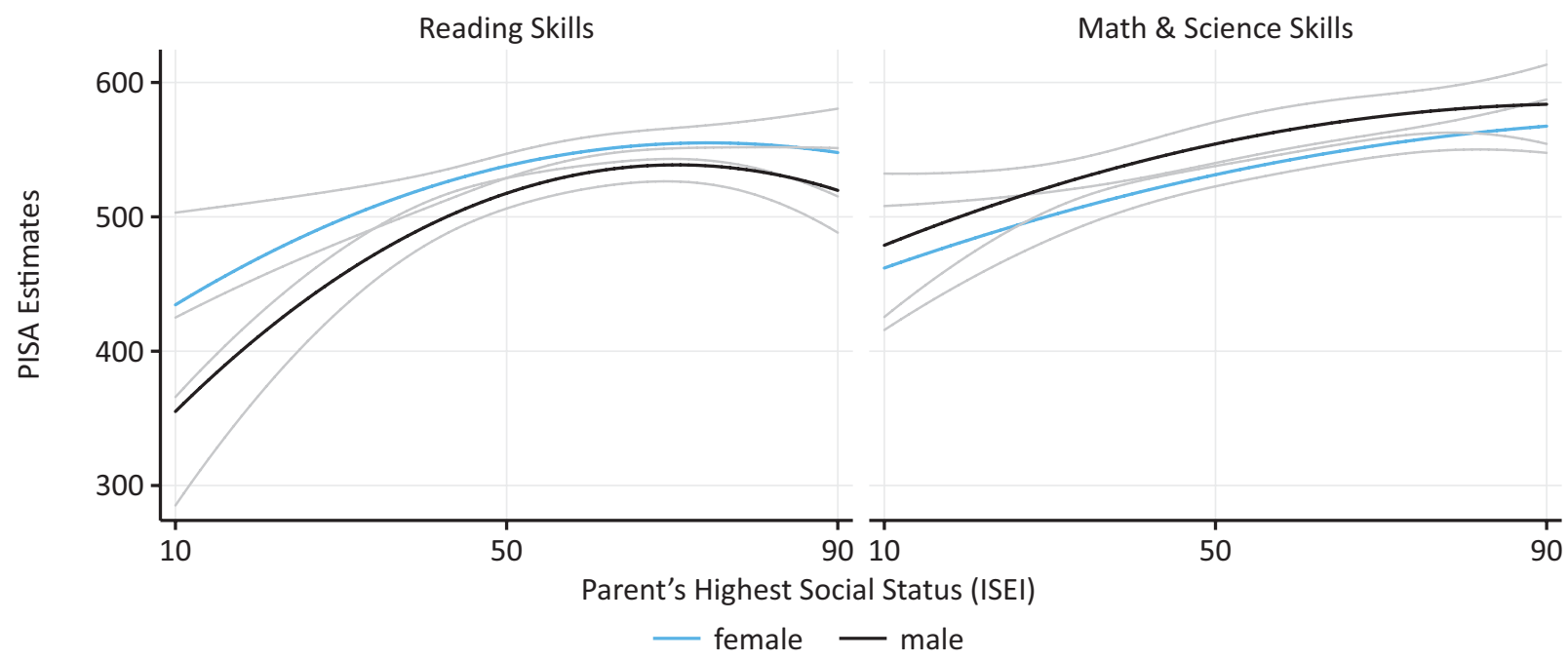

Figure 1. Predictions of reading and mathematics/science skills by parental social status (ISEI) and gender, grey lines: $95 \%-\mathrm{Cl}$.

Table 2. Effects on reading and mathematics/science skills (OLS coefficients). Source: PISA (2000) and TREE waves 1-9 (weighted; 2016).

\begin{tabular}{|c|c|c|c|}
\hline \multirow[b]{2}{*}{ Women } & $\begin{array}{l}\text { Warm estimate } \\
\text { in reading }\end{array}$ & \multicolumn{2}{|c|}{$\begin{array}{l}\text { Warm estimate in } \\
\text { mathematics/science }\end{array}$} \\
\hline & $18.86 * * \quad(7.097)$ & $-22.84^{*}$ & $(9.502)$ \\
\hline Highest parental ISEI (centred) & $1.805^{* * *}(0.338)$ & $1.240 * * *$ & $(0.273)$ \\
\hline Women*Highest parental ISEI (centred) & $(0.445)$ & 0.0274 & $(0.353)$ \\
\hline Highest parental ISEI (centred)*Highest parental ISEI (centred) & $-0.0501 * *(0.0155)$ & -0.0143 & $(0.0145)$ \\
\hline Women*Highest parental ISEI (centred)*Highest parental ISEI (centred) & $0.0209 \quad(0.0221)$ & 0.00393 & $(0.0177)$ \\
\hline Constant & $522.4 * * * \quad(5.835)$ & $557.5^{* * *}$ & (8.591) \\
\hline Observations & 2221 & 1960 & \\
\hline
\end{tabular}

Notes: Standard errors in parentheses; ${ }^{*} p<0.05,{ }^{* *} p<0.01,{ }^{* * *} p<0.001$.

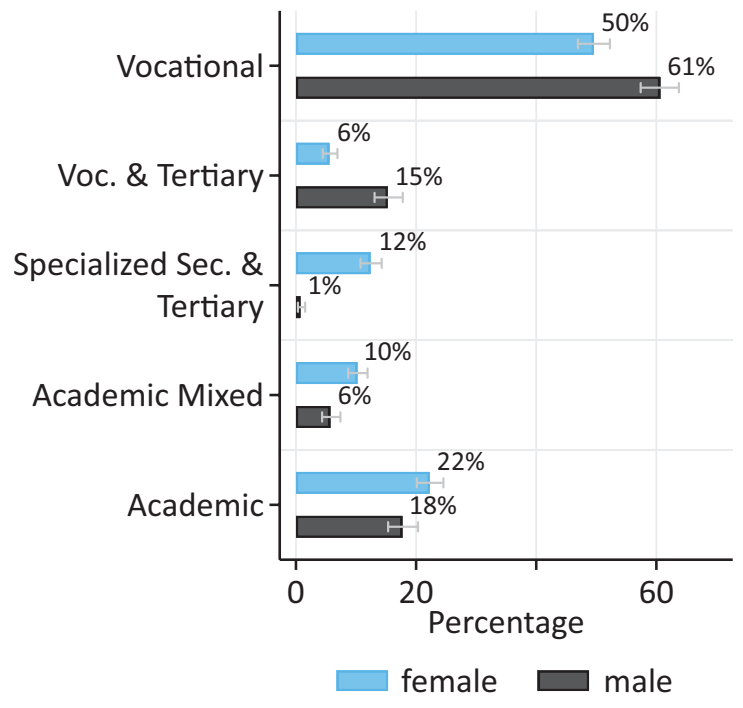

Figure 2. Distribution of men and women in the educational clusters, grey spikes: $95 \%-\mathrm{Cl}$.

prepare for tertiary education in the health care sector. The final two clusters contain the trajectories starting with general secondary education, followed either by the university of applied sciences or by the university. While the latter is balanced by gender, in the former, which also contains universities of teacher education, women are overrepresented.

The chronogram in Figure 3 displays the five clusters. The colours show the relative proportions of the different states at each point in time.

In the next step, we analyse whether social origin and gender are associated with the probability of belonging to a certain educational cluster. The results are displayed in Figure 4 and 5 and Tables 3 and 4 . We find a strong effect of social origin. Pupils growing up in families with lower socioeconomic status have a significantly higher probability of belonging to the vocational cluster. In other words, the lower the parental ISEI the higher the chance that they enter the labour market after their vocational training and do not pursue further education. An equally clear effect we find for cluster five: The higher the parental ISEI, the higher the probability that the students graduate baccalaureate school and enter university. We also find a moderate effect of social origin on the probability of belonging to the vocational \& tertiary and to the mixed academic cluster. Conversely, only the proba- 

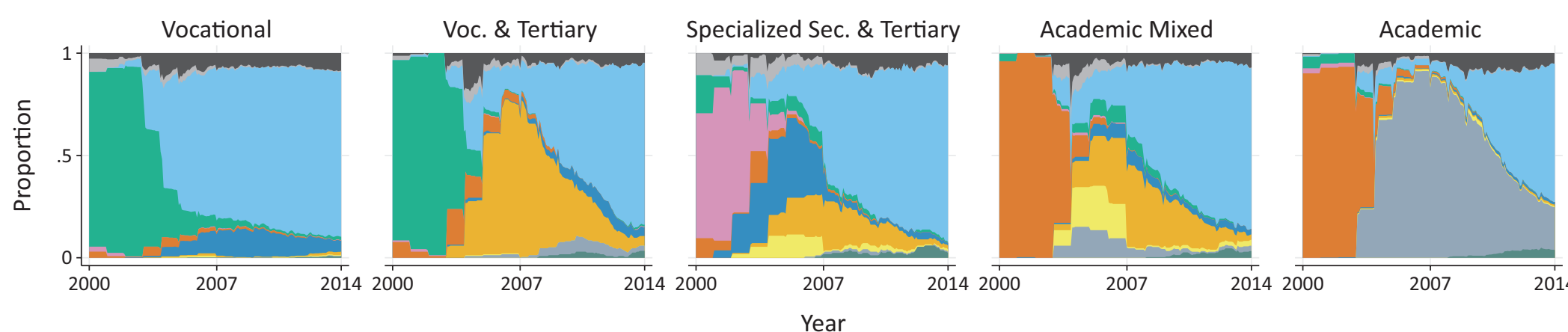

- NEET

Other educ. etc.

- Employment

VET

Secondary, spec.

- Secondary, academic

- Tertiary, vocational

- Univ. of applied sciences

Univ. of teacher education

- University

Advanced studies

Figure 3. Clusters of educational trajectories.
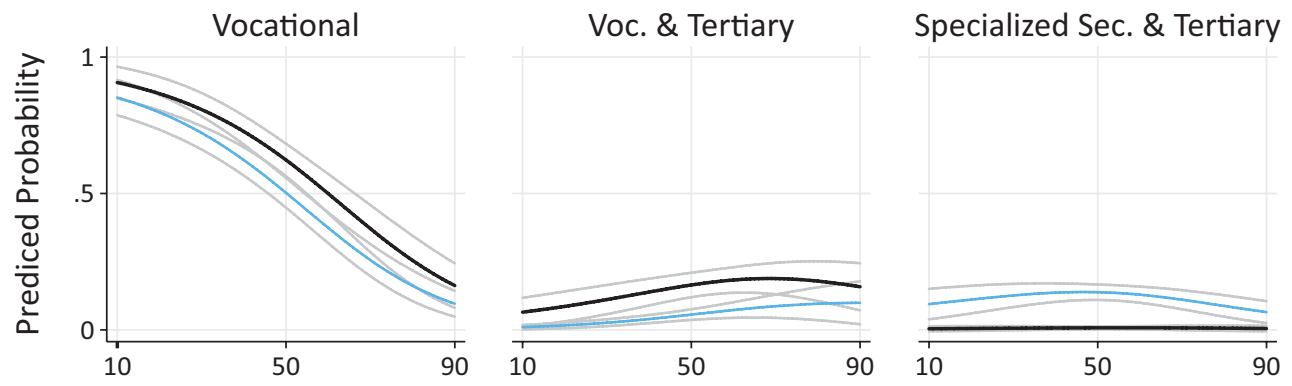

Academic Mixed

Academic

Parent's Highest Social Status (ISEI)
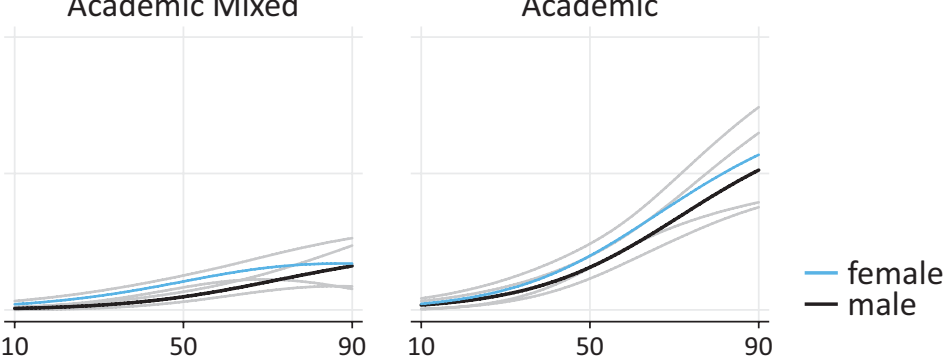

Figure 4. Probabilities of belonging to a certain cluster, by social origin and gender, total effect, grey lines: $95 \%-\mathrm{Cl}$.

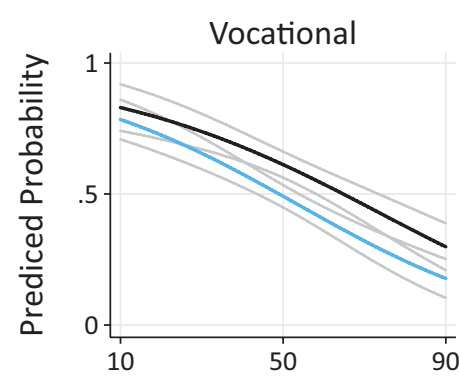

Voc. \& Tertiary

Specialized Sec. \& Tertiary

Academic Mixed

Academic
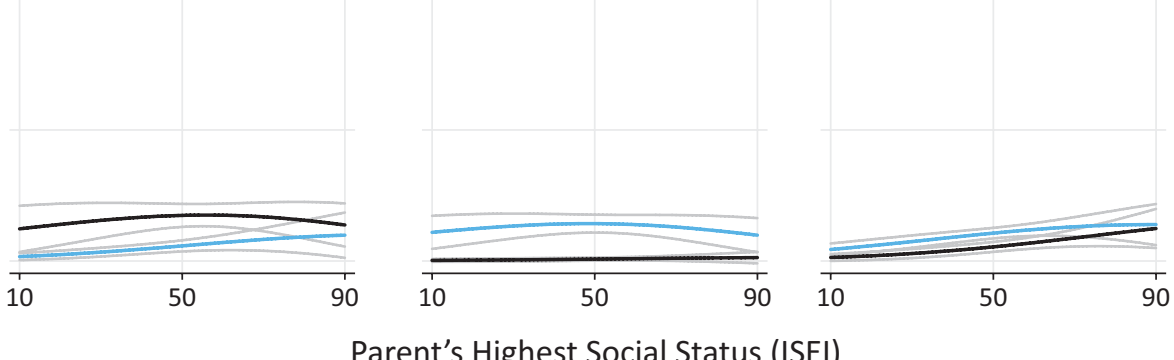

Parent's Highest Social Status (ISEI)

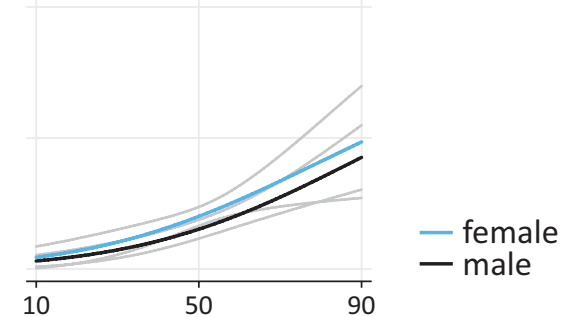

Figure 5. Probabilities of belonging to a certain cluster, by social origin and gender, direct effect, net of reading and mathematics/science skills, grey lines: $95 \%$-Cl. 
Table 3. Probability of belonging to a certain educational cluster (average marginal effects based on multinomial logistic regression). Source: PISA (2000) and TREE waves 1-9 (weighted; 2016).

\begin{tabular}{lccccc}
\hline & Vocational & Voc. \& Tertiary & Specialised Sec. \& Tertiary & Academic Mixed & Academic \\
\hline Women & $-0.106^{* * *}$ & $-0.0976^{* * *}$ & $0.118^{* * *}$ & $0.0466^{* * *}$ & 0.0393 \\
& $(0.0320)$ & $(0.0193)$ & $(0.0134)$ & $(0.0130)$ & $(0.0216)$ \\
Highest parental ISEI & $-0.0105^{* * *}$ & $0.00147^{* *}$ & -0.000181 & $0.00218^{* * *}$ & $0.00702^{* * *}$ \\
& $(0.000698)$ & $(0.000478)$ & $(0.000380)$ & $(0.000375)$ & $(0.000781)$ \\
\hline Observations & 2224 & 2224 & 2224 & 2224 & 2224 \\
\hline
\end{tabular}

Notes: Standard errors in parentheses; ${ }^{*} \mathrm{p}<0.05,{ }^{* *} \mathrm{p}<0.01,{ }^{* * *} \mathrm{p}<0.001$.

Table 4. Probability of belonging to a certain educational cluster (average marginal effects based on multinomial logistic regression). Source: PISA (2000) and TREE waves 1-9 (weighted; 2016).

\begin{tabular}{lccccc}
\hline & Vocational & Voc. \& Tertiary & $\begin{array}{c}\text { Specialised Sec. } \\
\text { \& Tertiary }\end{array}$ & Academic Mixed & Academic \\
\hline Women & $-0.108^{* * *}$ & $-0.103^{* * *}$ & $0.122^{* * *}$ & $0.0442^{* *}$ & 0.0451 \\
& $(0.0288)$ & $(0.0196)$ & $(0.0164)$ & $(0.0145)$ & $(0.0233)$ \\
Highest parental ISEI & $-0.00705^{* * *}$ & 0.000600 & -0.0000470 & $0.00125^{* *}$ & $0.00524^{* * *}$ \\
& $(0.000621)$ & $(0.000491)$ & $(0.000430)$ & $(0.000412)$ & $(0.000952)$ \\
Warm estimate in reading & $-0.00156^{* * *}$ & 0.000119 & 0.0000589 & $0.000472^{* * *}$ & $0.000913^{* * *}$ \\
& $(0.000229)$ & $(0.000140)$ & $(0.000130)$ & $(0.000123)$ & $(0.000189)$ \\
Warm estimate in & $-0.00121^{* * *}$ & $0.000264^{*}$ & -0.000193 & $0.000329^{* *}$ & $0.000809^{* * *}$ \\
mathematics/science & $(0.000207)$ & $(0.000129)$ & $(0.000114)$ & $(0.000111)$ & $(0.000130)$ \\
\hline Observations & 1960 & 1960 & 1960 & 1960 & 1960 \\
\hline
\end{tabular}

Notes: Standard errors in parentheses; ${ }^{*} \mathrm{p}<0.05,{ }^{* *} \mathrm{p}<0.01,{ }^{* * *} \mathrm{p}<0.001$.

bility of belonging to the specialised secondary \& tertiary cluster is not affected by social origin. These effects are only slightly reduced when controlling for reading, mathematics/science skills, suggesting that a large portion of the observed gradients stem from secondary rather from primary effects of social origin.

Introducing gender as an additional dimension, the picture remains very similar if we focus only on the most prevalent clusters: While the vocational cluster dominates for lower and middle origin pupils, the academic cluster is the most prevalent for high origin pupils. This general rule holds for both females and males; the only difference lies in the crossing point, which can be found at a lower level of the parental ISEI for females compared to males. These two clusters can be characterised by strong gradients with respect to social origin but only minor differences with respect to gender. The inverse pair of clusters is the specialised secondary and tertiary cluster and the vocational and tertiary cluster. For both, only a minor gradient of social origin can be found, but at the same time, both are strongly gendered. Because of this combination, the specialised secondary and tertiary cluster is an important cluster for females irrespectively of their social origin, while for males the same is true for the vocational and tertiary cluster. No interaction effects between social origin and gender can be found for any of the clusters (see Table 5 and 6).

In the following steps of our analyses, we estimate the effects of school trajectory, social origin and gender on the person's own labour market outcomes in 2014 at the age of about 30 years. We measure labour market outcomes in two ways: The person's own ISEI and their salary. For each outcome, we calculate two models, in the first, we estimate the total effect of social status and gender without controlling for educational trajectory. In the second model, we introduce the educational clusters. The remaining effects can then be interpreted as direct effects, that is, the portion of effect that is not mediated by the educational clusters. For the estimation of social status, we additionally control whether the measurement of the respondents ISEI is current (in 2014) or earlier, in case the person was not working in 2014. For

Table 5. Contrast in average marginal effect of parental ISEI (female vs. male).

\begin{tabular}{lccccc}
\hline & Vocational & Voc. \& Tertiary & Specialised Sec. \& Tertiary & Academic Mixed & Academic \\
\hline Highest parental ISEI: & -0.000532 & -0.000288 & -0.000362 & 0.000257 & 0.000924 \\
female vs. male & $(0.00146)$ & $(0.00112)$ & $(0.000675)$ & $(0.000743)$ & $(0.00161)$ \\
\hline Observations & 2224 & 2224 & 2224 & 2224 & 2224 \\
\hline
\end{tabular}

Notes: Standard errors in parentheses; ${ }^{*} p<0.05,{ }^{* *} p<0.01,{ }^{* * *} p<0.001$. Source: PISA (2000) and TREE waves 1-9 (weighted) (2016). 
Table 6. Contrast in average marginal effect of parental ISEI (female vs. male).

\begin{tabular}{|c|c|c|c|c|c|}
\hline & Vocational & Voc. \& Tertiary & Specialised Sec. \& Tertiary & Academic Mixed & Academic \\
\hline $\begin{array}{l}\text { Highest parental ISEI: } \\
\text { female vs. male }\end{array}$ & $\begin{array}{c}-0.000532 \\
(0.00146)\end{array}$ & $\begin{array}{c}-0.000288 \\
(0.00112)\end{array}$ & $\begin{array}{r}-0.000362 \\
(0.000675)\end{array}$ & $\begin{array}{c}0.000257 \\
(0.000743)\end{array}$ & $\begin{array}{c}0.000924 \\
(0.00161)\end{array}$ \\
\hline Observations & 1960 & 1960 & 1960 & 1960 & 1960 \\
\hline
\end{tabular}

Notes: Standard errors in parentheses; ${ }^{*} p<0.05,{ }^{* *} p<0.01,{ }^{* * *} p<0.001$. Source: PISA 2000 and TREE waves 1-9 (weighted) (2016).

the estimation of the salary, we control whether the person is self-employed or not.

We find a strong effect of the parents' social status on the respondents own social status, displayed in the left graph of Figure 6 (see also Table 5). The effects of the parents' social status are similar for men and women, interaction effects between gender and social origin are not significant. For both genders, the effect is stronger at the lower range of the parental ISEI. It is mitigated to a certain extent when we include the clusters of educational trajectories in the model but remains significant

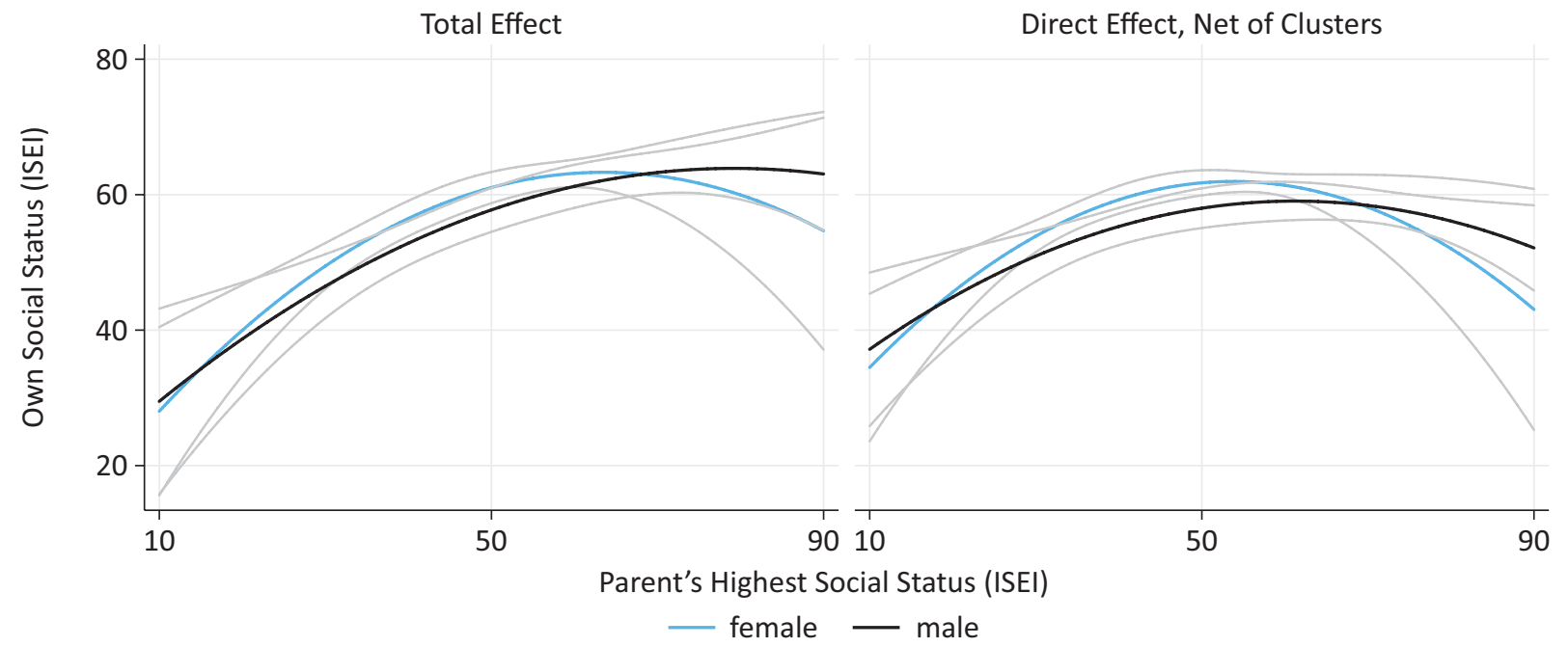

Figure 6. Predictions of social status (ISEI) in 2014 (age 30) by parental social status (ISEI) and gender, grey lines: $95 \%-\mathrm{Cl}$.

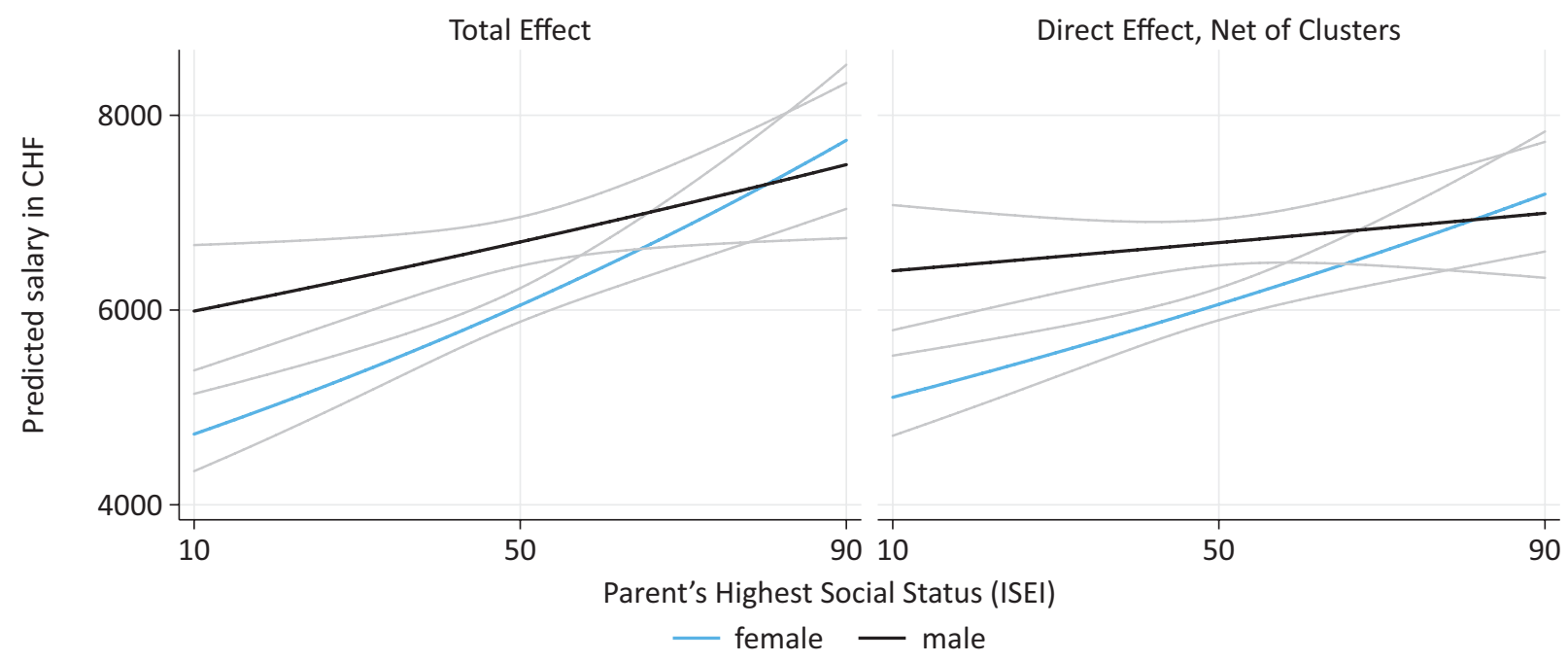

Figure 7. Predictions of salary in 2014 (age 30), by parental social status (ISEI) and gender; predictions back-transformed from log salary, grey lines: $95 \%-\mathrm{Cl}$. 
trol for the educational pathway, the effect disappears for men, but not for women. In the case of men, the educational trajectory mediates the effects of parental status. In other words: Men, as well as women, tend to follow different educational trajectories depending on their social origin. But when men are undergoing the same education, they then perform comparable jobs that do not differ in pay, regardless of the social status of their parents. In the case of women, on the other hand, the pay varies according to the status of the parents, even if they have the same education, possibly because they do not perform the same jobs. Women with parents who have a low social status are therefore facing a double disadvantage. The intersectional approach is useful to analyse the accumulation and interaction of multiple disadvantages at the time. One possible explanation is that it is less difficult for men with lower or medium family origin to reach reasonable wages because of the specificity of the Swiss dual educational system: In many occupations, a tertiary degree following vocational education can lead to a rather high salary. This concerns mainly male-dominated occupations, such as for example, banking, IT or technical professions. It seems that especially women with parents having a low socioeconomic status end up in low-paid jobs, even when the educational trajectory is controlled for.

Our final analyses concern the effects of educational pathways on status and salary (Table 7). The left side of Figure 8 displays the predicted ISEI by educational cluster. Persons directly entering the labour market after their apprenticeship or pursuing some tertiary vocational education (vocational cluster) reach the lowest social status

Table 7. Effects on social status (ISEI) (OLS coefficients).

\begin{tabular}{lcccc}
\hline & \multicolumn{3}{c}{ Current ISEI } \\
\hline Women & -5.159 & $(14.74)$ & -9.952 & $(12.76)$ \\
Highest parental ISEI & $1.137^{* *}$ & $(0.401)$ & $1.022^{* *}$ & $(0.343)$ \\
Women*Highest parental ISEI & 0.427 & $(0.619)$ & 0.522 & $(0.560)$ \\
Highest parental ISEI*Highest parental ISEI & $-0.00718^{*}$ & $(0.00360)$ & $-0.00835^{* * *}(0.00307)$ \\
Women*Highest parental ISEI*Highest parental ISEI & -0.00514 & $(0.00617)$ & -0.00602 & $(0.00578)$ \\
Not current & -2.990 & $(2.100)$ & -1.835 & $(2.586)$ \\
Voc. \& Tertiary & & & $20.56^{* * *}$ & $(1.738)$ \\
Specialised Sec. \& Tertiary & & & $19.01^{* * *}$ & $(1.848)$ \\
Academic Mixed & & & $21.21^{* * *}$ & $(1.655)$ \\
Academic & & & $22.84^{* * *}$ & $(1.680)$ \\
Voc. \& Tertiary*Not current & & & 7.890 & $(5.773)$ \\
Specialised Sec. \& Tertiary*Not current & & -2.118 & $(6.210)$ \\
Academic Mixed*Not current & & & -3.445 & $(5.822)$ \\
Academic*Not current & & & -3.390 & $(4.376)$ \\
Constant & & & $19.49 *$ & $(8.805)$ \\
\hline Observations & 18.96 & $(10.49)$ & & \\
\hline
\end{tabular}

Notes: Standard errors in parentheses; ${ }^{*} p<0.05,{ }^{* *} p<0.01,{ }^{* *} p<0.001$. Source: PISA (2000) and TREE waves 1-9 (weighted) (2016).

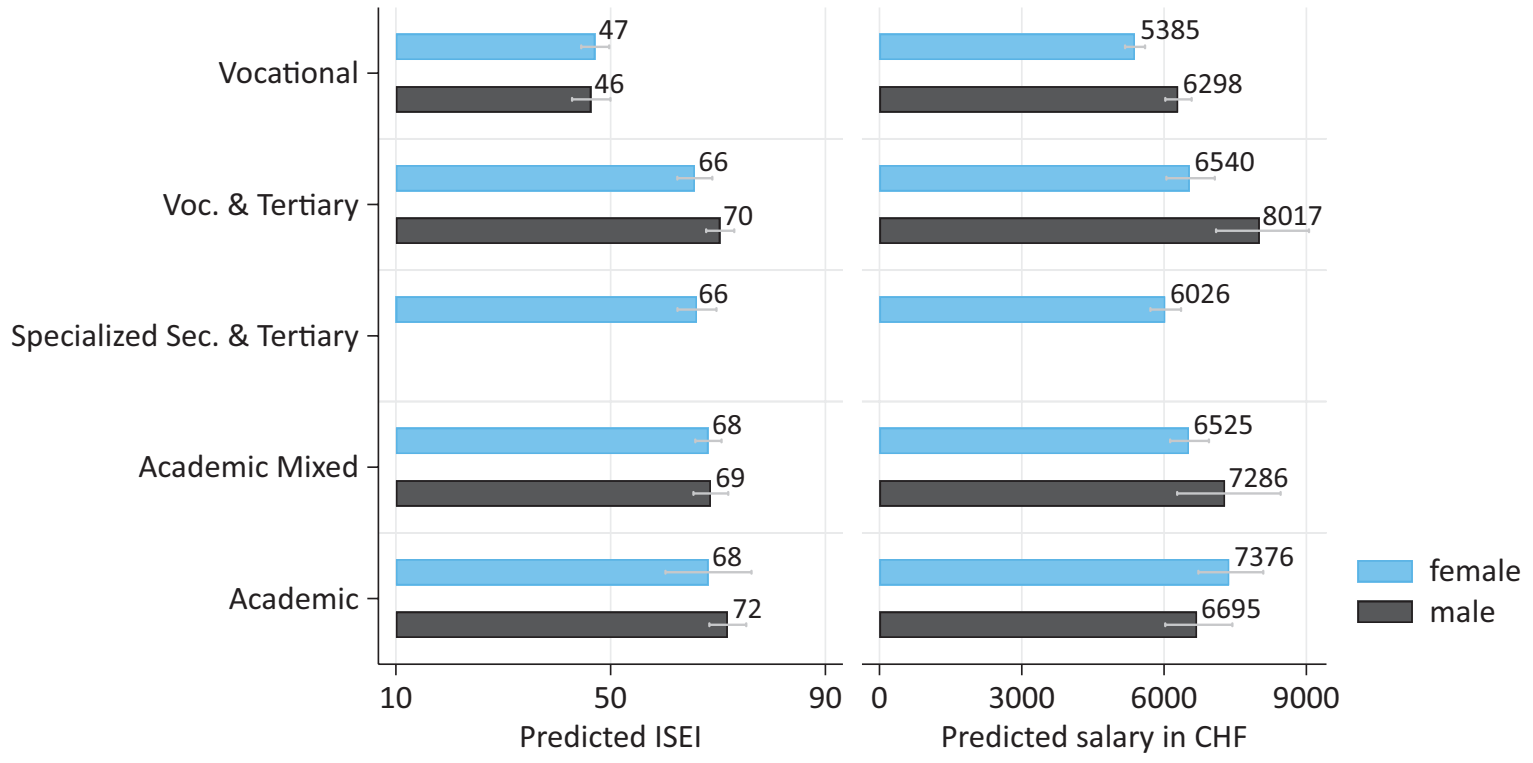

Figure 8. Predicted Social Status (ISEI) and Predicted Salary by Educational Cluster, grey spikes: 95\%-Cl. 
by far. This is true for men and women. The differences in social status between the other educational clusters are less pronounced. Persons following general secondary education and university (academic cluster) reach the highest status at age 30 . Men who complete vocational and tertiary education at the university of applied sciences are reaching a similarly high status.

Salary differences between different educational clusters are less pronounced (see the right graph of Figure 8). We find the within-cluster gender difference clearly more pronounced in terms of salary than in terms of status. On the other hand, there are two clusters that yield comparatively low salaries, the vocational and the specialised secondary \& tertiary cluster. In the two vocational clusters, we find a significant gender gap, with men reaching markedly higher salaries than women do. Some readers may find it surprising to find that the estimated salary of women who followed the academic educational pathway is higher than the one for men who followed the same pathway. It is, however, important to note that this difference is not statistically significant. In other words: While it is perfectly possible that in this specific population (highly educated, aged $\sim 30$, just left university) women have indeed a higher salary than men, this difference could be the result of chance alone.

\section{Robustness Checks}

To check the robustness of our results, we conducted some additional analyses. In particular, we sought to rule out three different sources of biases. First, while the cluster solutions found by the dynamic hamming procedure is plausible, it could be argued that it does not sufficiently separate individuals who entered the labour market directly after vocational education training and did not pursue any tertiary education from those with at least some tertiary education. In order to check this, we pre-defined a cluster with all individuals without any tertiary education and used optimal matching to form four clusters with the remaining respondents (Figure 9). This alters the

Table 8. Effects on log salary (OLS coefficients).

\begin{tabular}{lcccc}
\hline \multicolumn{4}{c}{ Log std. monthly gross salary } \\
\hline Women & $-0.269 * * *$ & $(0.0807)$ & $-0.263^{* * *}$ & $(0.0764)$ \\
Highest parental ISEI & $0.00280^{*}$ & $(0.00127)$ & 0.00110 & $(0.00119)$ \\
Women*Highest parental ISEI & $0.00337^{*}$ & $(0.00157)$ & $0.00318^{*}$ & $(0.00145)$ \\
Self-employed & -0.0906 & $(0.0838)$ & -0.0743 & $(0.0863)$ \\
Voc. \& Tertiary & & & $0.209 * * *$ & $(0.0409)$ \\
Specialised Sec. \& Tertiary & & & $0.0725^{*}$ & $(0.0330)$ \\
Academic Mixed & & $0.129 * * *$ & $(0.0321)$ \\
Academic & & & $0.172^{* * *}$ & $(0.372)$ \\
Constant & $8.672 * * *$ & $(0.0670)$ & $8.685^{* * *}$ & $(0.0634)$ \\
\hline Observations & 1860 & & 1860 &
\end{tabular}

Notes: Standard errors in parentheses; ${ }^{*} \mathrm{p}<0.05,{ }^{* *} \mathrm{p}<0.01,{ }^{* * *} \mathrm{p}<0.001$. Source: PISA (2000) and TREE waves 1-9 (weighted) (2016).

Table 9. Effects of educational clusters on social status and salary by gender (OLS coefficients).

\begin{tabular}{|c|c|c|c|c|}
\hline & \multicolumn{2}{|c|}{ Current ISEI } & \multicolumn{2}{|c|}{ Log std. monthly gross salary } \\
\hline & Men & Women & Men & Women \\
\hline Voc. \& Tertiary & $\begin{array}{l}24.02 * * * \\
(2.341)\end{array}$ & $\begin{array}{l}18.56^{* * *} \\
(2.210)\end{array}$ & $\begin{array}{c}0.241^{* * *} \\
(0.0663)\end{array}$ & $\begin{array}{l}0.194 * * * \\
(0.0449)\end{array}$ \\
\hline Specialised Sec. \& Tertiary & $\begin{array}{l}12.41 \\
(8.632)\end{array}$ & $\begin{array}{l}18.96 * * * \\
(2.154)\end{array}$ & $\begin{array}{c}-0.124 \\
(0.220)\end{array}$ & $\begin{array}{c}0.113^{* *} \\
(0.0341)\end{array}$ \\
\hline Academic Mixed & $\begin{array}{l}22.27 * * * \\
(2.445)\end{array}$ & $\begin{array}{l}21.09 * * * \\
(1.732)\end{array}$ & $\begin{array}{c}0.146 \\
(0.0792)\end{array}$ & $\begin{array}{l}0.192 * * * \\
(0.0369)\end{array}$ \\
\hline Academic & $\begin{array}{l}25.43 * * * \\
(2.529)\end{array}$ & $\begin{array}{l}21.10 * * * \\
(4.280)\end{array}$ & $\begin{array}{c}0.0613 \\
(0.0581)\end{array}$ & $\begin{array}{l}0.315^{* * *} \\
(0.0509)\end{array}$ \\
\hline Not current & $\begin{array}{c}-2.991 \\
(3.066)\end{array}$ & $\begin{array}{c}-2.388 \\
(2.763)\end{array}$ & & \\
\hline Self-employed & & & $\begin{array}{c}-0.0223 \\
(0.114)\end{array}$ & $\begin{array}{c}-0.0493 \\
(0.119)\end{array}$ \\
\hline Constant & $\begin{array}{l}46.52 * * * \\
(1.857)\end{array}$ & $\begin{array}{l}47.27^{* * *} \\
(1.344)\end{array}$ & $\begin{array}{l}8.748^{* * *} \\
(0.0227)\end{array}$ & $\begin{array}{l}8.593^{* * *} \\
(0.0204)\end{array}$ \\
\hline Observations & 872 & 1295 & 761 & 1136 \\
\hline
\end{tabular}



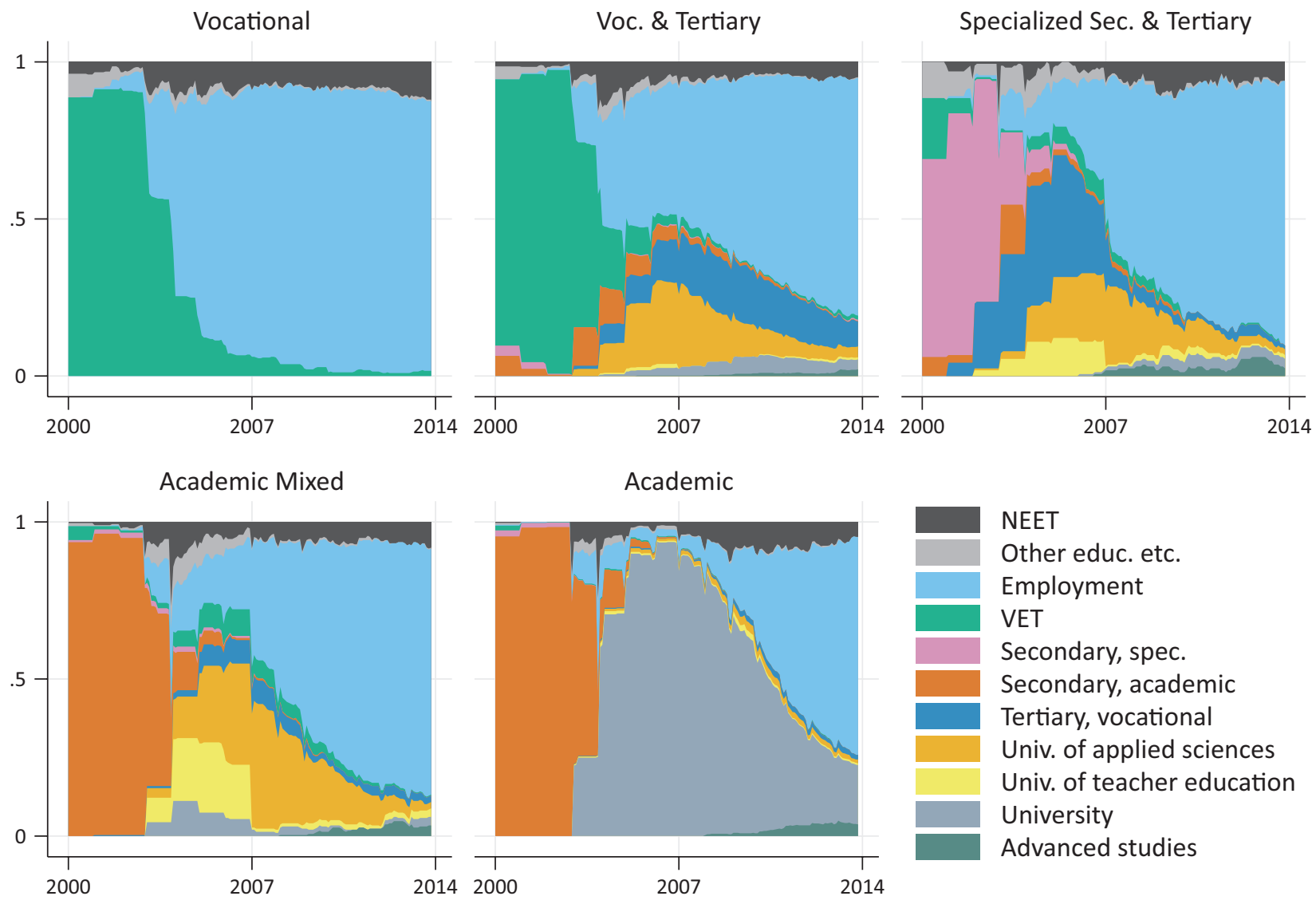

NEET

Other educ. etc.

Employment

VET

Secondary, spec.

Secondary, academic

Tertiary, vocational

Univ. of applied sciences

Univ. of teacher education

University

Advanced studies

Figure 9. Clusters of educational trajectories, solution with a separate cluster for VET \& employment.

size of the two vocational clusters (the second cluster becomes the biggest) but does not substantially change the results of the regressions (results not shown).

Second, at age 30, especially persons who completed tertiary education are in a critical phase of their occupational career. A few more years of experience in the labour market could increase their salary significantly. In order to take this into account, we re-estimated the mod- els predicting log salaries based on a restricted sample including only the respondents who completed their education at least two years prior (see the left panel of Table 10). Using the restricted sample increases the gender gap and decreases the effect of the parental social status of men compared to the original model. Further, as selfdeclarations of salaries are sometimes unrealistically low or high, in our last model, we excluded the highest and

Table 10. Effects of educational clusters on social status and salary by gender (OLS coefficients). Source: PISA (2000) and TREE waves 1-9 (weighted; 2016).

Log std. monthly gross salary

\begin{tabular}{|c|c|c|c|c|c|c|c|c|}
\hline \multirow[b]{2}{*}{ Women } & \multicolumn{4}{|c|}{ End of education at least 2 years ago } & \multicolumn{4}{|c|}{ Exclusion of the lowest and highest $1 \%$} \\
\hline & $-0.362^{* * *}$ & $(0.0856)$ & $-0.350 * * *$ & $(0.0778)$ & $-0.245^{* *}$ & $(0.0751)$ & $-0.243 * * *$ & $(0.0699)$ \\
\hline Highest parental ISEI & 0.00151 & $(0.00121)$ & -0.000286 & $(0.00106)$ & $0.00228 *$ & $(0.00109)$ & 0.000824 & $(0.00106)$ \\
\hline $\begin{array}{l}\text { Women*Highest } \\
\text { parental ISEI }\end{array}$ & $0.00496 * *$ & $(0.00163)$ & $0.00458 * *$ & $(0.00146)$ & $0.00295^{*}$ & $(0.00138)$ & $0.00278 *$ & $(0.00125)$ \\
\hline Self-employed & -0.0800 & $(0.0888)$ & -0.0618 & $(0.0896)$ & -0.0577 & $(0.0781)$ & -0.0408 & $(0.0796)$ \\
\hline Voc. \& Tertiary & & & $0.176^{* * *}$ & $(0.0254)$ & & & $0.170 * * *$ & $(0.0236)$ \\
\hline $\begin{array}{c}\text { Specialised Sec. } \\
\text { \& Tertiary }\end{array}$ & & & $0.0656^{*}$ & $(0.0310)$ & & & $0.0786^{*}$ & $(0.0316)$ \\
\hline Academic Mixed & & & $0.150^{* * *}$ & $(0.0339)$ & & & $0.143^{* * *}$ & $(0.0307)$ \\
\hline Academic & & & $0.202 * * *$ & (0.0299) & & & $0.144 * * *$ & $(0.0303)$ \\
\hline Constant & $8.744^{* * *}$ & $(0.0689)$ & $8.762 * * *$ & $(0.0609)$ & $8.689 * * *$ & $(0.0625)$ & $8.701 * * *$ & $(0.0587)$ \\
\hline Observations & 1591 & & 1591 & & 1829 & 1829 & & \\
\hline
\end{tabular}

Notes: Standard errors in parentheses; ${ }^{*} \mathrm{p}<0.05,{ }^{* *} \mathrm{p}<0.01,{ }^{* * *} \mathrm{p}<0.001$. 
the lowest percentage (see right panel of Table 10). This does not substantially alter our results.

Third, we calculated all our models using the highest parental education instead of the highest ISEI. The results are similar. We find one slight deviance concerning the effects on the person's own salary: Using parental education instead of parental ISEI, the interaction effect between parental origin and gender is not significant. However, as is the case with the parental ISEI, the effect of parental education is stronger for women than for men and women earn less than men on most parental educational levels (results are available upon the authors' request).

\section{Conclusions}

In our analyses, we tried to show a global picture of the intersectional effects of gender and social status on the educational trajectories and on subsequent labour market outcomes. The combination of sequence analyses and regressions allowed us to reduce the complexity of individual life courses and use them in explanatory models without sacrificing the strength of the panel data. Further, this procedure allowed us to get an overview of the entire post-compulsory educational trajectory and the first years in the labour market. Our primary aim was to visualise differences by parental status and gender.

In line with our theoretical considerations, we found that first, performance in reading, mathematics/science tasks distinctly differ by parental status and gender at the end of compulsory school. The higher the social status, the better the performance of boys and girls. Besides this origin effect, there is also a gender effect with girls performing better in reading tasks and boys in mathematical and science tasks. Although the interaction effect is not significant, mainly boys with lower status parents face a double disadvantage in the reading tasks. Second, boys and girls from different social family backgrounds follow varying educational trajectories.

Boys are overrepresented in the vocational tracks, while girls more often attend general secondary schools. We suspect that an important reason is the gendertypical choice of occupation. In the vocational track, the range of male-dominated occupations is much vaster and it subsequently offers better labour market prospects. Female dominated jobs that offer some labour market prospects usually require general secondary education. The choice of an educational pathway is consequential for subsequent labour market success. We show that men and women following the academic track, as well as men following the vocational \& tertiary track, reach the highest status, while individuals in the vocational cluster by far reach the lowest status.

In terms of salary, we find a strong gender pay gap, particularly within the vocational clusters. Despite the crucial importance of educational trajectories, effects of social origin remain significant and women especially face a "class pay gap". The presented overview shows that the post-millennial Swiss educational system is still stratified by parental status and gender. The argument often raised by public opinion that boys are disadvantaged at school proves to be only partially true when looking closely. It concerns mainly the reading skills of boys with disadvantaged family backgrounds. Next, girls cannot entirely transform their educational advantages into equal labour markets success. This again mainly affects girls from disadvantaged backgrounds who have the worst labour market prospects.

These analyses show that it is important to take an intersectional approach when analysing education and labour market inequalities. The strength of the presented analyses is the detailed description of young adults' educational trajectories and their first years in the labour market. With this approach, we are not able to explain in detail how these differences in our outcomes emerge. To get more insight into these mechanisms, one needs to limit the analyses on one or two outcomes. This concerns particularly the occurrence of horizontal segregation by parental status and gender and its effects on the different labour market outcomes. In addition, our operationalisation of social origin is limited. It would be interesting to combine different aspects of social origin, such as, for example, social class, status or education of the father and the mother, using an index to account for the family level of this factor. Alternatively, the distinct effects of the father's and the mother's social status on boys and girls should be analysed more closely. Gaining more knowledge about the different mechanisms, considering an intersectional approach of gender, social origin and possibly other attributes, for example, migrant status would also help to formulate policy advice.

\section{Acknowledgments}

This research was supported by the Doc.CH grants 155473 and 159169 of the Swiss National Science Foundation (SNSF). We thank the team of TREE-Data for their support and two anonymous reviewers as well as the editors of this special issue for their comments that greatly improved the manuscript.

\section{Conflict of Interests}

The authors declare no conflict of interests.

\section{References}

Adams, R., \& Wu, M. (2003). PISA Programme for international student assessment (PISA) PISA 2000 technical report: OECD Publishing.

Allmendinger, J., Ebner, C., \& Nikolai, R. (2010). Soziologische Bildungsforschung [Sociological educational research]. In R. Tippelt \& B. Schmidt (Eds.), Handbuch Bildungsforschung [Handbook of educational research] (3rd ed.). Wiesbaden: VS Verlag für Sozialwissenschaften | Springer Fachmedien. 
Becker, R. (2007). “Das katholische Arbeitermädchen vom Lande" - Ist die Bildungspolitik ein Opfer einer bildungssoziologischen Legende geworden? ["The Catholic workers' girl from the country"-Has education policy become a victim of an educational sociological legend?]. In C. Crotti, P. Gonon, \& W. Herzog (Eds.), Pädagogik und Politik: Historische und aktuelle Perspektiven. Festschrift für Fritz Osterwalder [Pedagogy and Politics: Historical and Current Perspectives. Festschrift for Fritz Osterwalder]. Bern Stuttgart Wien: Haupt Verlag.

Becker, R., Haunberger, S., \& Schubert, F. (2010). Studienfachwahl als Spezialfall der Ausbildungsentscheidung und Berufswahl [Choice of study subject as a special case of the training decision and career choice]. Zeitschrift für Arbeitsmarktforschung, 42(4), 292-310.

Becker, R., \& Lauterbach, W. (2010). Bildung als Privileg: Erklärungen und Befunde zu den Ursachen der Bildungsungleichheit [Education as a privilege: Explanations and findings on the causes of educational inequality] (4th ed.). Wiesbaden: VS Verlag für Sozialwissenschaften.

Becker, R., \& Müller, W. (2011). Bildungsungleichheiten nach Geschlecht und Herkunft im Wandel [Changing educational inequalities by gender and origin]. In A. Hadjar (Ed.), Geschlechtsspezifische Bildungsungleichheiten [Gender-specific educational inequalities]. Wiesbaden: VS Verlag für Sozialwissenschaften.

Beller, E. (2009). Bringing intergenerational social mobility research into the twenty-first century: Why mothers matter. American Sociological Review, 74(4), 507-528.

Blau, F. D., \& Kahn, L. M. (2017). The gender wage gap: Extent, trends, and explanations. Journal of Economic Literature, 55(3), 789-865.

Blossfeld, P. N. (2019). A multidimensional measure of social origin: theoretical perspectives, operationalization and empirical application in the field of educational inequality research. Quality \& Quantity, 53(3), 1347-1367.

Boudon, R. (1974). Education, opportunity and social inequality: Changing prospects in western society. New York, NY: John Wiley \& Sons.

Bourdieu, P., \& Passeron, J.-C. (1971). Die Illusion der Chancengleichheit: Untersuchungen zur Soziologie des Bildungswesens am Beispiel Frankreichs [The illusion of equal opportunities: Studies on the sociology of education using the example of France]. Stuttgart: Klett.

Breen, R., \& Goldthorpe, J. H. (1997). Explaining educational differentials towards a formal rational action theory. Rationality and Society, 9(3), 275-305.

Breen, R., Luijkx, R., Müller, W., \& Pollak, R. (2009). Longterm trends in educational inequality in Europe: Class inequalities and gender differences. European Sociological Review, 26(1), 31-48.

Brzinsky-Fay, C., \& Kohler, U. (2010). New developments in sequence analysis. Sociological Methods \& Research, 38(3), 359-364.

Buchmann, C., \& DiPrete, T. A. (2006). The growing female advantage in college completion: The role of family background and academic achievement. American Sociological Review, 71(4), 515-541.

Buchmann, M., \& Kriesi, I. (2012). Geschlechtstypische Berufswahl: Begabungszuschreibungen, Aspirationen und Institutionen [Gender-typical career choice: Talent attributions, aspirations and institutions]. In Soziologische Bildungsforschung [Sociological Educational Research] (pp. 256-280). Wiesbaden: Springer.

Charles, M. (2011). A world of difference: International trends in women's economic status. Annual Review of Sociology, 37, 355-371.

Charles, M., \& Bradley, K. (2002). Equal but separate? A cross-national study of sex segregation in higher education. American Sociological Review, 67(4), 573-599.

Charles, M., \& Bradley, K. (2009). Indulging our gendered selves? Sex segregation by field of study in 44 countries. American Journal of Sociology, 114(4), 924-976.

Dahrendorf, R. (1965). Bildung ist Bürgerrecht: Plädoyer für eine aktive Bildungspolitik [Education is a civil right: Plea for an active education policy]. Hamburg: Rohwolt.

DiPrete, T. A., \& Buchmann, C. (2013). The rise of women: The growing gender gap in education and what it means for american schools. New York, NY: Russell Sage Foundation.

Eagly, A. H., \& Diekman, A. B. (2006). What is the problem? Prejudice as an attitude-in-context. In J. F. Dovidio, P. Glick, \& L. A. Rudman (Eds.), On the nature of prejudice: Fifty years after Allport (pp. 19-35). Malden, MA: Blackwell Publishing.

Eagly, A. H., \& Karau, S. J. (2002). Role congruity theory of prejudice toward female leaders. Psychological Review, 109(3), 573.

Eagly, A. H., \& Sczesny, S. (2008). Stereotypes about women, men and leaders: Have time changed? In $\mathrm{M}$. K. Barreto, M. K. Ryan, \& M. T. Schmitt (Eds.), The glass ceiling in the 21st century: Understanding barriers to gender equality (pp. 21-47). Washington, DC: American Psychological Association.

England, P. (2010). The gender revolution uneven and stalled. Gender \& Society, 24(2), 149-166.

Entwisle, D. R., Alexander, K. L., \& Olson, L. S. (2007). Early schooling: the handicap of being poor and male. Sociology of Education, 80(2), 114-138.

Erikson, R., \& Jonsson, J. O. (1996). Can education be equalised? The Swedish case in comparative perspective. Boulder, CO: Westview Press.

Geißler, R. (2005). Die Metamorphose der Arbeitertochter zum Migrantensohn. Zum Wandel der Chancenstruktur im Bildungssystem nach Schicht, Geschlecht, Ethnie und deren Verknüpfungen [The 
metamorphosis of the worker's daughter to the migrant son. On the change of the opportunity structure in the educational system according to stratum, gender, ethnicity and their connections]. In P. A. Berger (Ed.), Institutionalisierte Ungleichheiten: wie das Bildungswesen Chancen blockiert [Institutionalised inequalities: How the education system blocks opportunities]. Weinheim and Munich: Juventa.

Glaesser, J., \& Cooper, B. (2012). Gender, parental education, and ability: Their interacting roles in predicting GCSE success. Cambridge Journal of Education, 42(4), 463-480.

Glauser, D. (2015). Berufsausbildung oder Allgemeinbildung: soziale Ungleichheiten beim Übergang in die Sekundarstufe II in der Schweiz [Vocational or general education: social inequalities in the transition to upper secondary education in Switzerland]. Wiesbaden: Springer Fachmedien.

Gomensoro, A., Meyer, T., Hupka-Brunner, S., Jann, B., Müller, B., Oesch, D., . . . Scharenberg, K. (2017). Employment situation at age thirty. results update of the Swiss panel survey TREE. Bern: TREE.

Gottburgsen, A., \& Gross, C. (2012). Welchen Beitrag leistet "Intersektionalität" zur Klärung von Kompetenzunterschieden bei Jugendlichen? [What contribution does "intersectionality" make to clarifying differences in competence among young people?]. In R. Becker \& H. Solga (Eds.), Soziologische Bildungsforschung [Sociological educational research]. Wiesbaden: Springer Fachmedien.

Halpin, B. (2010). Optimal matching analysis and lifecourse data: The importance of duration. Sociological Methods \& Research, 38(3), 365-388.

Halpin, B. (2017). SADI: Sequence analysis tools for Stata. Stata Journal, 17(3), 546-572.

Imdorf, C., \& Hupka-Brunner, S. (2015). Gender differences at labor market entry in Switzerland. In H.P. Blossfeld, J. Skopek, M. Triventi, \& S. Buchholz (Eds.), Gender, education and employment: An international comparison of school-to-work transitions (pp. 267-286). Cheltenham and Northampton: Edward Elgar Publishing.

Imdorf, C., Koomen, M., Murdoch, J., \& Guégnard, C. (2017). Do vocational pathways improve higher education access for women and men from less privileged social backgrounds? A comparison of vocational tracks to higher education in France and Switzerland. Rassegna Italiana di Sociologia, 58(2), 283-314.

Imdorf, C., Sacchi, S., Wohlgemuth, K., Cortesi, S., \& Schoch, A. (2014). How cantonal education systems in Switzerland promote gender-typical schoolto-work transitions. Swiss Journal of Sociology, 40(2), 175-196.

Korupp, S. E., Ganzeboom, H. B. G., \& Van Der Lippe, T. (2002). Do mothers matter? A comparison of models of the influence of mothers' and fathers' educational and occupational status on children's educational at- tainment. Quality and Quantity, 36(1), 17-42.

Kriesi, I., \& Buchmann, M. (2014). Beginning school transition and academic achievement in mid-elementary school: Does gender matter? In I. Schoon \& J. S. Eccles (Eds.), Gender differences in aspirations and attainment: A life course perspective. Cambridge: Cambridge University Press.

Lesnard, L. (2006). Optimal matching and social sciences. Lesnard, L. (2010). Setting cost in optimal matching to uncover contemporaneous socio-temporal patterns. Sociological Methods \& Research, 38(3), 389-419.

Marks, G. N. (2011). Issues in the conceptualisation and measurement of socioeconomic background: Do different measures generate different conclusions? Social Indicators Research, 104(2), 225-251.

McCall, L. (2005). The complexity of intersectionality. Signs, 30(3), 1771-1800.

Meraviglia, C., \& Buis, M. L. (2015). Class, status, and education: The influence of parental resources on IEO in Europe, 1893-1987. International Review of Social Research, 5(1), 35-60.

Mood, C. (2017). More than money: Social class, income, and the intergenerational persistence of advantage. Sociological Science, 4, 263-287.

Paulus, W., \& Blossfeld, H.-P. (2007). Schichtspezifische Präferenzen oder sozioökonomisches Entscheidungskalkül? Zur Rolle elterlicher Bildungsaspirationen im Entscheidungsprozess beim Übergang von der Grundschule in die Sekundarstufe [Stratum-specific preferences or socio-economic decision-making? On the role of parental educational aspirations in the decision-making process in the transition from primary to secondary education]. Zeitschrift für Pädagogik, 53(4), 491-508.

Peisert, H. (1967). Soziale Lage und Bildungschancen in Deutschland [Social situation and educational opportunities in Germany]. Munich: Piper.

Reimer, D., \& Pollak, R. (2005). The impact of social origin on the transition to tertiary education in West Germany 1983 and 1999. Mannheim: Mannheimer Zentrum für Europäische Sozialforschung, Universität Mannheim.

Rivera, L. A., \& Tilcsik, A. (2016). Class advantage, commitment penalty: The gendered effect of social class signals in an elite labor market. American Sociological Review, 81(6), 1097-1131.

Sacchi, S. (2011). Construction of TREE panel weights. In Documentation for the panel waves from 2000 to 2010, 2011. Bern: TREE.

Schwiter, K., Hupka-Brunner, S., Wehner, N., Huber, E., Kanji, S., Maihofer, A., \& Bergman, M. M. (2014). Warum sind Pflegefachmänner und Elektrikerinnen nach wie vor selten? Geschlechtersegregation in Ausbildungs-und Berufsverlaufen junger Erwachsener in der Schweiz [Why are nurses and electricians still rare? Gender segregation in the training and career paths of young adults in Switzerland]. Schweizerische Zeitschrift für Soziologie, 40(3), 401-428. 
Strand, S. (2014). Ethnicity, gender, social class and achievement gaps at age 16: Intersectionality and 'Getting it' for the white working class. Research Papers in Education, 29(2), 131-171.

Transitions from Education to Employment. (2016). Documentation on the first TREE cohort (TREE1) 2000-2016. Bern: TREE. van de Werfhorst, H. G. (2002). A detailed examination of the role of education in intergenerational social-class mobility. Social Science Information, 41(3), 407-438.

Warm, T. A. (1989). Weighted likelihood estimation of ability in item response theory. Psychometrika, 54(3), 427-450.

\section{About the Authors}

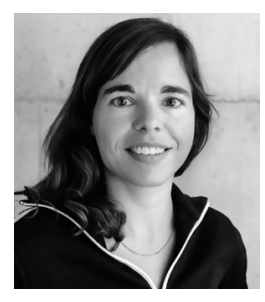

Barbara Zimmermann is a Doctoral Candidate at the Institute of Sociology of the University of Bern. She is a member of the Graduate School of the Interdisciplinary Centre for Gender Studies. Her main interests are different aspects of social inequality and social justice.

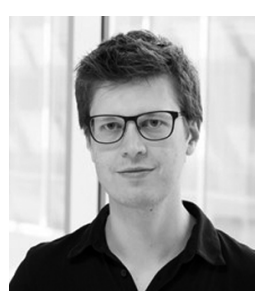

Simon Seiler received his PhD in Sociology from the University of Bern in 2018. He is interested in a broad range of substantive and methodological questions related to the causes, reproduction and consequences of inequality. In addition to his affiliation with the Institute of Sociology of the University of Bern, he is currently employed by the Swiss Centre of Expertise in the Social Sciences (FORS) in Lausanne and the Interfaculty Centre of Educational Research of the University of Bern. 